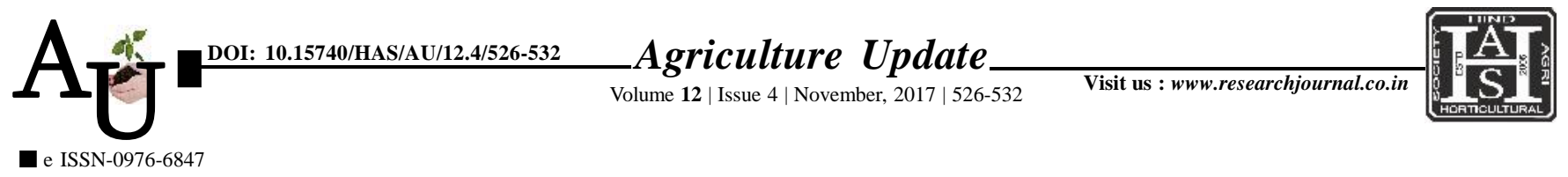

\title{
Research Article: Socio-economic status and expenditure pattern of the organic farmers of selected agro-climatic zones of northern Karnataka versus conventional farmers
}

\section{RAJESHWARI DESAI AND K.V. ASHALATHA}

Article Chronicle:

Received :

05.07.2017;

Revised :

17.08.2017;

Accepted :

03.09.2017

KEY WoRDS:

Socio-economic status, Expenditure pattern, Organic farmers, Conventional farmers

Author for correspondence : RAJESHWARI DESAI AICRP-H.Sc. (Family Resource Management), Main Agricultural Research Station (UAS), DHARWAD (KARNATAKA) INDIA

Email:rajmanohardesaiuas @ gmail.com

See end of the article for authors' affiliations
SUMMARY : Socio-economic status (SES) is a measure of a family's economic and social position in the society. Sociologists often use socio-economic status as a means of predicting quality of life. The present study was conducted in three agro climatic zones of northern Karnataka with a sample size of each 150 organic and conventional farmers, thus comprising of total of 300 samples. The results revealed that the socio-economic status of the organic farmers was higher as compared to conventional farmers. The farm expenditure grabbed the lion's share in the total family income expenditure followed by food. All the selected respondents under the study were able to make minimum savings from their earnings and none of the families was not free of loans, however, the percentage was meagre.

How to cite this article : Desai, Rajeshwari and Ashalatha, K.V. (2017). Socio-economic status and expenditure pattern of the organic farmers of selected agro-climatic zones of northern Karnataka versus conventional farmers. Agric. Update, 12(4): 526-532; DOI : 10.15740/HAS/AU/12.4/526-532. 